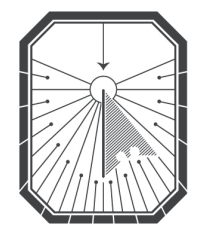

KYIV-MOHYLA

LAW \& POLITICS JOURNAL

KYIV-MOHYLA SCHOLARLY PEER-REVIEWED JOURNALS

Humanizing (Anti)Corruption: The Socio-Legal Values of a Human Rights-Based Approach to Corruption

Author(s): Bruna de Castro e Silva

Source: Kyiv-Mohyla Law and Politics Journal 5 (2019): 59-81

Published by: National University of Kyiv-Mohyla Academy

http://kmlpj.ukma.edu.ua/ 


\title{
Humanizing (Anti)Corruption: The Socio-Legal Values of a Human Rights-Based Approach to Corruption' ${ }^{1}$
}

\author{
Bruna de Castro e Silva \\ Lawyer \\ University of Gothenburg, Sweden
}

\begin{abstract}
This article intends to contribute to the current academic and policy debate on the values of determining whether a particular human rights violation was caused by a corrupt behavior; and to defend a human rights-based approach to corruption, based on its added socio-legal values. With this purpose, it analyzes and compares the legal reasoning and socio-legal dynamics of three human rights court cases involving and not involving corruption. By applying a directed content analysis combined with a socio-legal interpretative technique, the study explores and compares the rationality and the values addressed in both corrupt and non-corrupt cases. The results reveal that there are interconnected and mutually reinforcing socio-legal values in applying a human rights lens to combating corruption: (i) it is an improvement towards the justiciability of economic and social rights; (ii) it is a change of paradigm from the insufficient criminal approach to a focus on the social harm; and (iii) it is a more satisfactory approach to the overlapping harmful effects of corruption and inequality. The combination of these values can be used as a legal empowerment strategy, with a particular social accountability dimension, in order to strengthen the disadvantaged, and fight the encroachment caused by corruption on the enjoyment of human rights, especially economic and social rights.
\end{abstract}

Key Words: human rights-based approach, corruption, economic and social rights, justiciability, socio-legal values, social harm, inequality, legal empowerment.

\section{0}

\section{Introduction}

In recent years, scholars have vastly held that corruption is an enormous obstacle to the realization of human rights. "The money stolen through corruption every year was enough to feed the world's hungry 80 times over. From 2002 to 2009 , developing

1 The author would like to thank the participants at the Fourth Interdisciplinary Corruption Research Forum "Varieties of (Anti-)Corruption: Learning From the Past for the Future", Kyiv 2019 for helpful comments, and also acknowledge that this article originated from the homonymous dissertation submitted to the Erasmus Mundus Master's Program in Human Rights Policy and Practice, the University of Gothenburg, Sweden. 
countries lost $\$ 8.44$ trillion to illicit financial flows, equivalent to 10 times more than the foreign aid they received." ${ }^{2}$

However, anti-corruption international law and global policies highlight the criminal aspects of corruption and pay less attention to a people-centered approach, downplaying its drastic economic and social consequences and the impact of corrupt behavior on human rights. " ${ }^{3}$ The anti-corruption practice and human rights practice seem to evolve in parallel tracks, in separate forums, and with distinct agendas". Therefore, it is necessary to understand how human rights law and practice can frame anti-corruption and what the value is of doing so, in order to build bridges between those mechanisms and increase compliance with both systems.

Although a deeper analysis of the link between corruption and human rights is still nascent in the literature, and more research needs to be undertaken on this topic, ${ }^{5}$ it has been claimed that a human rights lens "provides a valuable normative framework" to address corruption. Notwithstanding, the problem is that this assertion by UN human rights institutions and part of the scholarship has been questioned, and a human rights-based approach has been criticized. ${ }^{6}$

Considering this problem, the research questions addressed are: $(i)$ What is the socio-legalvalue of a human rights-based approach to corruption?(ii) Why try to determine whether a particular human rights violation was caused by corruption? Additionally, the complementary sub-questions: (iii) What is the value of identifying whether especially economic and social rights violations were caused by corruption?

In order to answer these questions, I analyze and compare the legal reasoning and socio-legal dynamics of three human rights court cases involving and not involving corruption. By applying directed content analysis combined with a socio-legal interpretative technique, this study explores and compares the rationality and values addressed in both corrupt and non-corrupt cases.

2 Leonie Hensgen, "Corruption and Human Rights - Making the Connection at the United Nations." Max Planck Yearbook of United Nations Law Online 17, no. 1 (2013): 216. Accessed May 9, 2018. doi:10.1163/18757413-90000085. http://booksandjournals.brillonline.com.ezproxy.ub.gu. se/content/journals/10.1163/18757413-9000oo85.

4 Raoul Wallenberg Institute. “The Nexus Between Anti-Corruption and Human Rights.” Updated 2018. Accessed February 11, 2019. https://rwi.lu.se/publications/nexus-anti-corruption-humanrights/:2.

5 Raoul Wallenberg Institute. "Anti-Corruption and Human Rights: How to Become Mutually Reinforcing." Updated 2018. Accessed May 24, 2018. http://rwi.lu.se/publications/anticorruption-human-rights-become-mutually-reinforcing/.

6 Anne Peters, "Corruption as a Violation of International Human Rights," European Journal of International Law 29, no. 4 (2018): 1251-87. doi:10.1093/ejil/chyo7o. https://doi.org/10.1093/ejil/ chyo7o. 


\section{Theory \& Literature}

\section{Corruption as a Human Rights Violation: the Critique of "Human Rightism"}

There is some apprehensiveness among scholars of international law on employing a human rights lens to address corruption. Professor Anne Peters ${ }^{7}$ summarizes this critical account: "Some international lawyers might complain that this smacks of 'human rightism' or of a 'hubris' of international human rights. Indeed, there is a risk of overusing human rights language. Therefore, the human rights-based approach to corruption should not be employed as a panacea. The language of law generally (and of rights, more particularly) is a limited one, as the critique of the human rights-based approach to corruption points out."

As one of its representatives, Pellet contributes to the critique of "human rightism": "[Human rights law] is, and can only be, the art of the possible, and by wanting to ask the impossible of it, the 'human rightists' harm the cause that they intend to defend more than they serve it." 8 The author highlights one of the procedures that constitute the most dangerous tendencies of human rightism, and compares it to "wishful thinking," in the sense that human rightists tend to take their desires for realities and to consider tendencies still in their infancy or, worse, that exist only in their dreams, as legal truths.

Rose also explains why applying a human rights lens to combating corruption might not be the best approach, since human rights law is limited as a vocabulary describing the harms of corruption, which results in a potential overuse or misappropriation of this rhetoric. ${ }^{10}$ She exemplifies that claims of a right to a corruption-free society, or the insistence on a human rights approach to the issue of corruption held by lawyers and activists may push this rhetoric beyond its limits - with the possible effect of weakening the fabric of this body of law.

Therefore, it is essential to emphasize that this criticism is pertinent to this study. In opposition to the idea that the human rights lens could complement the traditional criminal law approach to corruption, this critique argues that doing so would result in overusing human rights language - "because human rights are certainly a wonderful thing, but they are not everything." "1

However, as will be discussed, at the end of my study I will disagree with this group of scholars, and my goal is to demonstrate with this analysis that there are

7 Peters, Corruption, 1286.

8 Alain Pellet, “"Human Rightism” and International Law,” The Italian Yearbook of

International Law Online 10, no. 1 (200o): 3-16. doi:10.1163/22116130oXooo13. https://doi.

org/10.1163/22116130oXooo13.

9 Pellet, Human Rightism, 5 .

10 Cecily Rose, “The Limitations of a Human Rights Approach to Corruption," International and

Comparative Law Quarterly 65, no. 2 (2016): 405-438, doi:10.1017/S oo205893160ooo38. https://

doi.org/10.1017/S 0020589316000038.

11

Pellet, Human Rightism, 15. 
interconnected and mutually reinforcing socio-legal values in employing a human rights lens to address corruption.

\section{Justiciability of Economic and Social Rights}

Economic and Social rights are in the spotlight of this analysis - shaping the sub research question. The reason is hereby explained. Professor Peters ${ }^{12}$ informs that " $[\mathrm{s}]$ ocial and economic rights(hereafter- "ESC-rights") are the set of rights most affected by corruption. However, so far, the question at what point a social human right is actually violated in an individual case in the sense of constituting a breach of international law triggering state responsibility has not been fully resolved." She exemplifies that it is so far unclear which facts can be meaningfully qualified as a "restriction of," or as an "interference with," a social right, as we do about civil and political rights.

The author accurately points out that the more significant and basically unresolved question is: "how to exactly determine at which point a concrete ESC-right is violated."'This challenge is often described as a lack of justiciability. It is not only a procedural matter but relates to the material structure of the ESC-rights." 13

Since "social rights violations very often result from systemic governance deficiencies, based on political budgetary decisions, and affect large groups of people,"14 the question of whether and how systemic governance deficits can be articulated in the language of rights is not only relevant for corruption. The situation of corruption is only one modality of impinging notably on ESC-rights. ${ }^{15}$

In this sense, Anne Peters' account on the correlation between addressing corruption and the justiciability of ESC-rights is part of the adopted theoretical framework.

\section{Existing Gaps in the Criminal Approach and the Theory of Social Harm}

At both domestic and international levels, the traditional legal account on anticorruption is a criminal one. The purpose of criminal proceedings is - broadly speaking - to identify the person responsible for the offense. However, focusing criminal proceedings on the perpetrator can neglect the victim of corruption. "Furthermore, the criminal approach does not offer ways of addressing the structural problems caused

\footnotetext{
12 Peters, Corruption, 1285.

13 Anne Peters, "The Risk and Opportunity of the Humanisation of International Anti-Corruption Law: A Rejoinder to Kevin E. Davis and Franco Peirone." In EJIL: Talk! The Blog of the European Journal of International Law. 2019. Accessed March 26, 2019. https://www.ejiltalk.org/the-riskand-opportunity-of-the-humanisation-of-international-anti-corruption-law-a-rejoinder-tokevin-e-davis-and-franco-peirone/\#more-169o4.

14 Peters, Corruption, 2.

15 Peters, Corruption, 2.
} 
by corruption. It is concentrated, by its very nature, on a single offense, and typically cannot address the collective and general effects of corruption." 16

Barkhouse, Hoyland, and Limon explain that applying the concept of Social Harm could help move anti-corruption policy away from a narrow focus on corruption as an economic crime to be sanctioned under criminal law, to a comprehensive understanding and approach designed to respect, protect and fulfill human rights, and promote societal well-being. ${ }^{17}$ Widening the focus of anti-corruption efforts in this way, to address the consequences of corruption for individual people and society, enables the application of international law, with potentially far-reaching consequences.

"Social Harm is a concept recognized in human rights law, for it encompasses the social, economic, psychological and environmental injury or damage inflicted on society by the acts of individuals, organizations or governments (national or international). It has allowed an assessment of illegal and harmful acts beyond domestic criminal justice systems, by providing a bridge to international human rights law." 18

Additionally, the concept of Social Harm is reflected in the preamble of the United Nations Convention Against Corruption"19: "the seriousness of problems and threats posed by corruption to the stability and security of societies, undermining the institutions and values of democracy, ethical values and justice," and the Convention states that "a comprehensive and multidisciplinary approach is required to prevent and combat corruption effectively."

\section{Legal Empowerment}

There has been an evolution of the concept of legal empowerment throughout recent years, but a consensus arises from the similarities shared by the several definitions and the UN Secretary-General's report on legal empowerment: "Legal empowerment is broad and multi-faceted in nature; it does not consist of a single strategy and certainly does not constitute a magic pill for alleviating poverty. Nevertheless, the consensus does suggest a core concept: Legal empowerment is the use of law specifically to strengthen the disadvantaged". ${ }^{20}$

16 Human Rights Council. "Final Report of the Human Rights Council Advisory Committee on the Issue of the Negative Impact of Corruption on the Enjoyment of Human Rights: A/HRC/28/73." United Nations, 2015. Accessed December 25, 2019 https://www.ohchr.org/en/hrbodies/hrc/ regularsessions/session28/pages/listreports.aspx.

Angela Barkhouse, Hugo Hoyland, and Marc Limon. "Corruption: A Human Rights Impact Assessment." Updated 2018. Accessed January 20, 2019. https://www.universal-rights.org/urgpolicy-reports/corruption-human-rights-impact-assessment/:6.

18 Barkhouse, Corruption, 6.

19 United Nations Convention Against Corruption. UNCAC. UN General Assembly. October 31, 2003. https://www.unodc.org/unodc/en/corruption/tools_and_publications/UN-conventionagainst-corruption.html. 
There are four key elements of the concept that deserve further explanation in the light of this research. The first element, "The use of law, involves not just legislation and court rulings, but the many regulations, ordinances, processes, agreements and traditional justice systems that constitute the law for the disadvantaged." ${ }^{21}$

In the present context, the law in question that can empower the poor and disadvantaged is international human rights law. One way of strengthening the linkages to human rights discourse would perhaps be to view legal empowerment as a sub-set of the broader HRBA discourse. Thus, Sengupta examines the legal empowerment process from the human rights perspective and argues that in order to effect real change, it is important to define legal empowerment in terms of the recognition of basic human rights and ensure that the poor actually have the opportunity to exercise these rights. ${ }^{22}$

The second element of the definition, "Specifically," captures the reality that legal empowerment features activities and strategies that focus on the disadvantaged. Such efforts include legal reforms exclusively or mainly aiming to benefit disadvantaged populations." ${ }^{23}$ Therefore, the human rights-based approach constitutes a strategy that, in combination with the other theoretical premises, and in conformity with the phenomena here investigated, can be used to focus on the disadvantaged.

The third element, "Strengthen," captures the empowerment aspect of the concept (...) The term also reflects the fact that legal empowerment is both a process and a goal." ${ }^{24}$ In this study, strength through legal empowerment is directly connected to giving the poor and marginalized, who are also the primary victims of corruption, protagonism towards a people-centered approach to fighting corruption.

Lastly, the interpretation of who is "disadvantaged" in this work is intrinsically connected with the consideration of the overlapping harmful effects of corruption and inequality (which will be further explored in Section 6.4.2).

\section{Methods}

\section{Multiple-Case Study}

This study applies a comparative design using a multiple-case study approach employing a qualitative research strategy. Alan Bryman explains that "a multiple-case (or multi-case) study occurs whenever the number of cases examined exceeds one." 25 The main argument in favor of a multiple-case study is that it improves theory building. "By comparing two or more cases, the researcher is in a better position to establish the

Golub, Empowerment, 6.

Sengupta 2008, cited in Banik, Dan. "Legal Empowerment as a Conceptual and Operational

Tool in Poverty Eradication."Hague Journal on the Rule of Law 1, no. o1 (2009): 117-31. doi:10.1017/S 1876404509001171. https://doi.org/10.1017/S 1876404509001171:123.

Golub, Empowerment, 6.

Golub, Empowerment, 6.

Bryman, Alan. Social Research Methods. Fifth edition. (Oxford: Oxford University Press, 2016): 74. 
circumstances in which a theory will or will not hold." ${ }^{26}$ Furthermore, the comparison may itself suggest concepts that are relevant to an emerging theory.

Cases were selected on the basis that they represent extreme types, ${ }^{27}$ in other words, they are pioneering precedents in their respective regional jurisprudences on the matter of ESC-rights, and a step forward on the justiciability of those rights. The three decisions were considered "historic milestones" and a step forward for the interdependence and indivisibility between civil and political rights, on the one hand, and economic, social, cultural and environmental rights, on the other. The cases are: (i) Lagos del Campo v. Peru. Series C. No. 340, Inter-American Court of Human Rights (IACtHR), 3 Aug 2017; (ii) Gonzales Lluy YOtrosv. Ecuador. Series C No. 298, Inter-American Court of Human Rights (IACtHR), 1 Sep 2015; and (iii) The Registered Trustees of the SocioEconomic Rights and Accountability Project (SERAP) v. the Federal Republic of Nigeria and Universal Basic Education Commission. ECW/CCJ/JUD/o7/10, Community Court of Justice of the Economic Community of West African States (ECOWAS), 30 Nov 2010.

The reason why this study focuses on ESC-rights instead of another category of human rights (e. g. civil and political rights), or simply human rights in general, relies on the theoretical framework; following Anne Peters's ${ }^{28}$ premises that (i) corrupt acts or omissions can under certain conditions technically be qualified as violating notably social rights; and (ii) corruption is one modality of impinging especially on ESC-rights.

"With case selection approach such as this, the findings that are common to the cases can be just as interesting and important as those that differentiate them." ${ }^{29} \mathrm{By}$ strategically choosing human rights court cases in this way, I can establish the common and divergent factors that lay behind the legal reasoning and the dynamics of the courts' decision-making processes, evaluating whether or not the consequences of corrupt and non-corrupt behaviors resulted in ESC-rights violations. By doing so, I can ultimately investigate the value of trying to determine whether a particular human rights violation was caused by corruption.

The reason for choosing one case involving corruption, and two cases not involving corruption is: by comparing the legal reasoning of whether a particular human rights violation was caused by corruption, on the one hand, and by other types of behaviors, on the other hand, this study will further demonstrate what differentiates the interpretation of whether or not a human rights violation has occurred when it is a general case or a case involving corrupt behavior. The commonalities and dissonances of the cases will shed light on the proposed inquiries, and expose how claims of ESC-rights violations were recognized or rejected, based on what values and legal fundaments.

26 Eisenhardt 1989; Yin 2009, cited in Bryman, Social Research Methods, 74.

27 Bryman, Social Research Methods, 75.

28 Anne Peters, "The Risk and Opportunity of the Humanisation of International Anti-Corruption Law: A Rejoinder to Kevin E. Davis and Franco Peirone." In EJIL: Talk! The Blog of the European Journal of International Law., 2019. Accessed March 26, 2019. https://www.ejiltalk.org/the-riskand-opportunity-of-the-humanisation-of-international-anti-corruption-law-a-rejoinder-tokevin-e-davis-and-franco-peirone/\#more-16904. 


\section{Directed content analysis}

The first applied technique for data analysis is Directed content analysis. When an existing theory or prior research about a phenomenon would benefit from further description, directed content analysis can be used."This approach aims to validate or extend conceptually a theoretical framework or theory". ${ }^{30}$ Therefore, this research uses this method to contribute to Anne Peters'31 account on the humanization of International Anti-Corruption law, and to support her arguments by extending the examination of the adopted theoretical framework.

A formative matrix of themes and related categories was deductively derived from (1) Anne Peters'32 account of Justiciability of Economic and Social Rights; (2) The Theory of Social Harm ${ }^{33}$; and (3) "The Concept of Legal Empowerment." ${ }^{44}$ In line with the deductive approach, the interpretations of the categories were also linked to existing theories in order to draw inferences.

Table 1

DEDUCTIVE FORMATIVE CATEGORIZATION MATRIX.

\begin{tabular}{|c|c|c|}
\hline $\begin{array}{l}\text { THEORETICAL } \\
\text { FRAMEWORK }\end{array}$ & THEME & $\begin{array}{l}\text { CATEGORY (MANIFEST AND/OR LATENT; IN VIVO } \\
\text { AND/OR ABSTRACT) }\end{array}$ \\
\hline \multirow{4}{*}{$\begin{array}{l}\text { Justiciability of } \\
\text { Economic and Social } \\
\text { Rights } 35\end{array}$} & \multirow{4}{*}{$\begin{array}{l}\text { Legal reasoning on } \\
\text { ESC-rights' encroachment } \\
\text { trough systemic governance } \\
\text { deficiencies }\end{array}$} & a) Violation of ESC-rights through one of the branches of \\
\hline & & government \\
\hline & & b) Maximum available resources ("maximum efforts"); \\
\hline & & c) Existing institutions not functioning properly \\
\hline \multirow{3}{*}{$\begin{array}{l}\text { Theory of Social } \\
\text { Harm }^{36}\end{array}$} & \multirow{3}{*}{$\begin{array}{l}\text { Assessment of illegal and } \\
\text { harmful corrupt and non- } \\
\text { corrupt acts and behaviors }\end{array}$} & a) People-centered approach: considers the victims, the \\
\hline & & human dimension and social implications of the conduct \\
\hline & & $\begin{array}{l}\text { b) The victim is overlooked: negligence or omission } \\
\text { regarding the social harm caused }\end{array}$ \\
\hline Legal & Social, political and economic & a) Marginalization and vulnerability affect the victims \\
\hline Empowerment ${ }^{37}$ & factors/context of the cases & $\begin{array}{l}\text { and overlap with the effects of corrupt and non-corrupt } \\
\text { behaviors }\end{array}$ \\
\hline
\end{tabular}

Source: Author's original

30 Hsiu-Fang Hsieh, and Sarah E. Shannon. "Three Approaches to Qualitative Content Analysis."Qualitative health research 15, no. 9 (2005): 1281. doi:10.1177/1049732305276687. https:// doi.org/10.1177\%2F1049732305276687.

31 Peters, Humanisation.

32 Peters, Humanisation.

33 Barkhouse, Corruption.

34 Golub, Empowerment.

35 Peters, Humanisation.

36 Barkhouse, Corruption.

37 Golub, Empowerment. 


\section{Socio-legal research}

The second technique for data analysis and interpretation is socio-legal research. Although there is no agreed definition of socio-legal studies, ${ }^{38}$ this study follows the Socio-Legal Studies Association (SLSA), which conceives the method as embracing "disciplines and subjects concerned with law as a social institution, with the social effects of law, legal processes, institutions and services and with the influence of social, political and economic factors on the law and legal institutions." 39

“The 'socio' in socio-legal studies means to us an interface with a context within which law exists, be that a sociological, historical, economic, geographical or another context." 40 Its purpose will generally be "to facilitate a future change, either in the law itself, or in the manner of its administration" 41 ; and the method is also called "law reform research" or "law in context." ${ }^{2}$ Socio-legal studies are an interdisciplinary alternative and a challenge to doctrinal studies of law. The "socio" in socio-legal studies does not refer to sociology or social sciences, but represents "an interface with a context within which law exists." 43

Social-legal research is an adequate technique to analyze the case data because this research aims to extrapolate the doctrinal analysis of the intersections between international human rights law and international anti-corruption law and look at the values of a reconceptualization of particular corrupt behaviors as actual violations of human rights.

Traditional doctrinal legal research does not suffice to address the proposed research questions. It is necessary to consider the influence of social, political, and economic factors on the harmful effects of corruption on mainly ESC-rights, in order to further understand the values of a human rights-based approach to corruption.

The advantages of this technique are that by putting the legal institution of corruption in context, it sheds light on the influence of social, political, and economic factors involved when corrupt behaviors affect human rights. This approach challenges the traditional criminal account applied to anti-corruption laws and policy, and reveals the values of adding a human rights-based approach to corruption, in which the focus on the victims reveals the socioeconomic aspects of the encroachment of human rights by corruption.

38 Dermot Feenan, “Exploring the 'Socio' of Socio-Legal Studies." In Exploring the 'Socio' of SocioLegal Studies. Vol. 38. Edited by Dermot Feenan, 3-19. Palgrave Macmillan Socio-Legal Studies. (London: Macmillan Education UK; Imprint; Palgrave, 2013): 21.

$41 \quad$ Paul Chynoweth, "Legal Research." In Advanced Research Methods in the Built Environment. ed. Andrew Knight and Leslie Ruddock. (Chichester, West Sussex, United Kingdom, Ames, Iowa: Wiley, 2008): 3 o.

42 Arthurs 1983, cited in Chynoweth, Legal Research, 30.

43 Sally Wheeler, and P. A. Thomas. "Socio-Legal Studies." In Law $(S)$ Futures. ed. D. Hayton, 267-79. (Oxford: Hart Publishing, 200o). 


\section{The Cases}

\section{Lagos del Campo v. Peru (IACtHR)}

In 1989, Lagos del Campo was discharged from the company where he had worked as an electrician for over 13 years. Lagos del Campo conducted a magazine interview in the capacity of president-elect of his union, in which he criticized the company for exerting pressure and threatening workers to influence union elections. Lagos del Campo was fired after the interview in response to his statements. After the second instance Labor Court upheld Lagos del Campo's dismissal, the former unionist was not reinstated in his job, was ineligible to receive compensation or benefits, and lost the possibility of accessing a retirement pension.

This case marked the first time the IACtHR condemned "the violation of Article 26 of the American Convention on Human Rights" 44 for denying the plaintiff the right to work and for infringing upon his rights to labor stability and association. The court found a violation of Lagos del Campo's ESC-rights, suggesting that by denying Lagos del Campo an adequate judicial forum to defend his labor rights, the state failed to use maximum available resources to protect the right to work and associated rights.

The court found violations of the rights above, as well as Lagos del Campo's right to a fair trial and judicial protection. The court held that the State's obligation to respect the right to work includes the provision of effective legal mechanisms through which worker claims of unjustified firings in the private sector could be brought and remedied through reinstatement and other measures. The Peruvian state failed to adopt appropriate measures to protect against violations of the right to work attributable to third parties. Because the Peruvian court supported the improper dismissal in its judicial system, the State violated the so-called "Obligation to Protect" individuals against human rights violations caused by third parties. In this sense, the IACtHR ordered compensatory damages, including lost salary, a retirement pension, and social benefits, as well as additional damages for emotional distress.

This first judgment of the Inter-American Court of Human Rights recognizing the direct enforceability of ESC-rights is a breakthrough case within the Inter-American regional human rights system, and strengthens global recognition of ESC-rights broadly. The Special Rapporteurship on Economic, Social, Cultural and Environmental Rights of the Inter-American Commission on Human Rights ${ }^{45}$ has welcomed the decision as a "historic milestone" and "a step forward in the region for the interdependence and indivisibility between civil and political rights, on the one hand, and economic, social, cultural and environmental rights, on the other."

Lagos Del Campo v. Peru, 4 (Inter-American Court of Human Rights August 31, 2017), http:// www.corteidh.or.cr/docs/casos/articulos/seriec_340_esp.pdf. 


\section{Gonzales Lluy YOtros v. Ecuador (IACtHR)}

In 1998, when Talía was three years old, she was infected with the HIV virus while receiving a blood transfusion on which the respective serological tests were not done. The blood was obtained from a blood bank of the Red Cross, and the transfusion was done at a private clinic in Ecuador. After Talía was infected, her mother sought criminal and civil justice, as well as payment of damages. However, she did not succeed. ${ }^{46}$

When Talía was five years old, she was banned from a public primary school, after her health condition was disclaimed. Talía's mother filed a judicial complaint against the Ministry of Education and Culture, the school principal and the teacher, alleging deprivation of Talía's right to education, and requested her reintegration into school, as well as the payment of damages. Nevertheless, the Ecuadorian court did not decide in favor of Talía. ${ }^{47}$

The Inter-American Court educed that the State bears the duty of the supervision and control of health services, even if offered by a private entity. It found that the blood bank that provided the blood that was transfused to Talía was insufficiently monitored and inspected by the State. This severe omission had allowed blood which had not been subjected to the most basic security tests, such as HIV tests, to be delivered to Talía's family for transfusion, resulting in her infection and consequent permanent damage to her health. ${ }^{48}$

The IACtHR concluded that Ecuador was responsible for the violation of the duty to inspect and supervise the provision of health services (private and public) arising from the right to health and the obligation not to expose life to risk enshrined in Articles 5 and $4 .{ }^{49}$ Therefore, the negligence that had led Talía to contract HIV, which had occurred while she was in the care of a private entity, was attributable to the State..$^{50}$

Furthermore, following the UN Committee on Economic, Social and Cultural Rights, the Court held that in order to ensure the right to education, "four essential and interrelated features should be fulfilled on all educational levels: (i) availability, (ii) accessibility, (iii) acceptability and (iv) adaptability." 51

46 The Secretariat of the Inter-American Court of Human Rights, "Non official brief: I/A

Court H. R., Case of Gonzales Lluy et al. v. Ecuador. Preliminary Objections, Merits, Reparations and Costs. Judgment of September 1, 2015. Series C No. 298".

The Secretariat of the Inter-American Court of Human Rights.

48 Gonzales Lluy Y Otros V. Ecuador (Inter-American Court of Human Rights September 1, 2015), accessed March 28, 2019, http://www.corteidh.or.cr/docs/casos/articulos/seriec_298_esp.pdf. of the 1969 American Convention on Human Rights, (Pact of San Jose Costa Rica), Organization of American States (November 22, 1969), https://www.oas.org/dil/access_to_information_

American_Convention_on_Human_Rights.pdf.

$5^{\circ} \quad$ The Secretariat of the Inter-American Court of Human Rights, "Non official brief: I/A Court H. R., Case of Gonzales Lluy et al. v. Ecuador. Preliminary Objections, Merits, Reparations and Costs. Judgment of September 1, 2015. Series C No. 298".

$5^{1} \quad$ Gonzales Lluy Y Otros V. Ecuador at 68. 
Regarding Talía's expulsion from school, the Court acknowledged that there was no adaptability of the educational environment to Talía's health situation..$^{52}$ In this sense, the IACtHR concluded that "Talía had suffered discrimination resulting from her status as a female child living in poverty and with HIV, and the Ecuadorian state violated her right to education, under Article 13 of the Protocol of San Salvador, in relation to Articles 1(1) and 19 of the ACHR." ${ }^{53}$

\section{SERAPv. Nigeria (ECOWAS)}

In 2005, Nigeria's anti-corruption commission started an investigation into allegations of corruption at the Universal Basic Education Commission (UBEC), a government agency which provides additional federal funding support for schools in disadvantaged areas of the country. ${ }^{54}$

An investigation by the Independent Corrupt Practices and Other Related Offences Commission (ICPC) was launched in response to a petition filed by the Nigerian NGO SERAP (The Registered Trustee of the Socio-Economic Rights and Accountability Project), based on information from whistleblowers and SERAP's own investigative efforts. "Its final report detailed extensive corruption and mismanagement in the handling of approximately $\$ 270$ million in government funds during 2005 and 2006; the report found evidence that funds meant for building and repairing schools and classrooms had been diverted to fraudulent front companies, while in other cases state officials had overpaid favored contractors for work that was either substandard or not done at all." 55

In 2007, SERAP used the findings of the ICPC as evidence to submit a human rights claim at the ECOWAS Court, arguing that the kind of corruption documented was not an isolated case, but an example of systematic high-level corruption and theft of funds meant for primary education in Nigeria.

The NGO claimed that due to this type of corruption, Nigeria has been unable to attain an acceptable level of education, and this reality reflects the sordid statistic that "over five million Nigerian children have no access to primary education, and there is a poor learning environment disseminated across the country". ${ }^{66}$ Furthermore, SERAP reasoned that the Nigerian government contributed to these problems by failing to

The Secretariat of the Inter-American Court of Human Rights, "Non official brief: I/A

Court H. R., Case of Gonzales Lluy et al. v. Ecuador. Preliminary Objections, Merits, Reparations and Costs. Judgment of September 1, 2015. Series C No. 298".

Gonzales Lluy Y Otros V. Ecuador at 88.

Adetokunbo Mumuni. "Legal Remedies for Grand Corruption: Litigating Corruption in International Human Rights Tribunals: SERAP Before the ECOWAS Court." Updated 2016. Accessed March 3, 2019. https://www.opensocietyfoundations.org/publications/legal-remediesgrand-corruption. 
seriously address allegations of corruption at the highest levels of government. Finally, it was emphasized that corruption destroys the people's natural wealth and public resources, and is the primary cause of the problems denying the majority of the citizens' access to quality education.

"Overall, the case was based on the provisions of Article 4(g) of the 1993 Revised Treaty of ECOWAS, as well as Articles 1, 2, 17, 21 and 22 of the ACHPR. The core substantive rights involved were the right to education, the right of the people not to dispossessed of their wealth and natural resources, and the right of people to economic and social development." 57

The court found that "[ $t$ ] he UBEC, by the law establishing it, has a responsibility to ensure that the funds they disburse to the Nigerian states are utilized for the purposes for which they were disbursed." 58 Therefore, the UBEC cannot be exempt from responsibility if funds given to the state are not adequately accounted for, since the agency has the onus to monitor the use of the funds, hence the power given to the UBEC to refuse further disbursements.

The court agreed that the embezzlement, theft, or even mismanagement of funds intended for the education sector would have a negative impact on education since "it reduces the amount of money made available to provide education to the people." 59

However, the decision emphasized that "There must be a clear linkage between the acts of corruption and a denial of the right to education. In a vast country like Nigeria, with her massive resources, one can hardly say that an isolated act of corruption contained in a report will have such devastating consequence as a denial of the right to education, even though as earlier pointed out it has a negative impact on education." 60

According to the court, "whilst steps are being taken to recover the funds or prosecute the suspects, as the case may be, it is in order that [the government] should take the necessary steps to provide the money to cover the shortfall to ensure a smooth implementation of the education program, lest a section of the people should be denied a right to education". ${ }^{61}$

The Registered Trustees of the Socio-Economic Rights and Accountability Project (SERAP)

V. The Federal Republic of Nigeria and Universal Basic Education Commission, 2 (Community

Court of Justice of the Economic Community of West African States November 30, 2010),

https://ihrda.uwazi.io/en/document/qrb6wqua4frswtjqwichxgvi?page=1.

$5^{8}$ Mumuni, Legal Remedies, 7.

59 The Registered Trustees of the Socio-Economic Rights and Accountability Project (SERAP) V. The

Federal Republic of Nigeria and Universal Basic Education Commission at 4.

6o The Registered Trustees of the Socio-Economic Rights and Accountability Project (SERAP) V. The

Federal Republic of Nigeria and Universal Basic Education Commission, 4.

61 The Registered Trustees of the Socio-Economic Rights and Accountability Project (SERAP) V. The

Federal Republic of Nigeria and Universal Basic Education Commission, 5. 


\section{Findings}

First Value: The Advancement of the Justiciability of Economic and Social Rights

The analysis of Theme 1 and respective categories illustrates Anne Peters' 62 observation regarding whether and how systemic governance deficits can be articulated in the language of rights. As she affirms, this problematic is not only relevant for corruption, once" $[\mathrm{t}]$ he situation of corruption is only one modality of impinging notably on ESC-rights."

In this sense, the way governance deficits encroach ESC-rights was observed in the analysis of the three categories.

Applying Peters' 63 account on the complexity of justiciability of ESC-rights, a common and interesting pattern was found within this theme: the encroachment of ESC-rights through one of the branches of government was part of the legal reasoning in all cases. However, in the SERAP case, in contrast to the other ones, that common argument did not lead to a recognition of an actual violation of ESC-rights.

The legal reasoning sustaining the decisions in both the Lagos del Campo and Ecuador cases - even though these are not corruption cases - is the encroachment on ESC-rights through one of the branches of government, therefore, in line with legal reasoning in the SERAP case. The ECOWAS acknowledged that the Executive's failure in inspecting and supervising the funds allocated for primary education necessarily had a negative impact on education. Which indicates, in other words, an impingement on ESC-rights through one of the branches of government.

Still, because it was not possible to prove a direct causal link between the act or omission of the State and the denial of the right to education, it was not possible, according to the Court, to find Nigeria in violation of its human rights obligations under the ACHPR. ${ }^{64}$ In this respect, Professor Peters ${ }^{65}$ clarifies that "the conceptual juridical work towards defining ESC-rights violations which trigger state responsibility and potentially reparation (as opposed to vague statements of noncompliance) is only in its infancy."

Although the doctrinal issue of causality prevented Nigeria's corrupt behavior to be considered an actual legal violation in that specific case, the value addressed in the ECOWAS legal reasoning is clearly there: it is an improvement towards the justiciability of ESC-rights, since the decision recognizes Nigeria's failure, through the Executive power, in inspecting and supervising the funds allocated for primary education, which impinged on the enjoyment of that right. Yet, "[b]ecause social rights violations very often result from systemic governance deficiencies, based on political budgetary

\footnotetext{
62 Peters, Humanisation.

63 Peters, Humanisation.

64 Barkhouse, Corruption, 7

65 Peters, Humanisation, 2.
} 
decisions, affect large groups of people, and pose threshold questions, the problem of causation is ubiquitous here - notonly with regard to corruption."66

Notwithstanding the lack of causality, the SERAP case is highly significant in the context of more comprehensive efforts to reconceptualize the prosecution of corruption as an ESC-rights violation and deciding in favor of the justiciability of the right to education under the ACHPR. The ECOWAS Court set an important regional and international precedent. ${ }^{67}$

Consequently, since "corruption is one modality of impinging especially on ESC-rights," 68 the case data support the conclusion that one value of trying to determine whether a particular human rights violation was caused by corruption is the advancement on the justiciability of ESC-rights, especially when considering how ESC-rights are negatively affected through one of the branches of government, or, in other words, systemic governance deficits.

\section{Second Value: Change of Paradigm Applying the Theory of Social Harm}

The contrasting findings within Theme 2 show that, in the Lagos del Campo and Ecuador cases, the IACtHR considers the victims and the negative consequences affecting their lives; whereas in the SERAP case, the final word of the ECOWAS overlooks the victims, purely applying a criminal approach to corruption. In this regard, the UN Human Rights Council ${ }^{69}$ observes that "[c]riminal prosecution is not, however, an effective tool for remedying the negative consequences of corruption for the individual, for specific groups or for society in general, since from a human rights perspective, States are required not only to prosecute such crimes but also to take measures to address the negative impact of corruption (...) In that sense, a human rights perspective to combating corruption and its effects is complementary to criminal law."

Anne Peters also illuminates this approach: "[o]verall, the infusion of international human rights law into efforts to combat corruption seems apt to complement or bolster the criminalization of corruption and, to that extent, has benign effects." Hence, a human rights perspective on the impact of corruption can add an approach that moves the victim to the center of the fight against corruption. It does so by emphasizing the negative impacts that corruption brings to the individual concerned, to groups of individuals typically affected by corruption (which are very often marginalized groups), and to society overall. ${ }^{70}$

A human rights-based approach to corruption may contribute to a better understanding of its effects - notably, its human dimension and social implications-

66 Peters, Humanisation, 2.

67 Barkhouse, Corruption, 7.

68 Peters, Humanisation, 2.

69 Human Rights Council, "Final report of the Human Rights Council Advisory Committee on the issue of the negative impact of corruption on the enjoyment of human rights," 10. 
and can be an essential step towards making corruption a public issue. "In that way, the social impact of corruption is made visible; this generates awareness in society about the consequences of this scourge and creates new alliances in the fight against corruption." 71

In this sense, another value of determining whether the consequences of corruption include human rights violations is a change of paradigm from the insufficient criminal approach to considering the human dimension and social implications of corruption, based on the Theory of Social Harm.

A human rights-based approach to anti-corruption policy-making may also help to focus international efforts on those who are most at risk, most marginalized and most vulnerable, or, according to the terminology of the 203 o Agenda for Sustainable Development, those who are "left furthest behind." 72 The marginalized are most of the people whose human rights are violated through corruption, as will be further discussed below in the analysis of Theme 3 .

\section{Third Value: Consideration of Overlapping Harmful Effects of Corruption and Inequality - Corruption Hits Poor People Hardest}

It is a consensus at both the international anticorruption system level and scholarship that the most vulnerable and marginalized are the ones mostly suffering the negative impacts of corruption. Transparency International ${ }^{73}$ assertively affirms that "[y]ear after year, it is the same. Our Global Corruption Barometer confirms that corruption hits poor people hardest — with devastating consequences." In this sense, "[c] orruption is a perpetrator and perpetuator of poverty and inequality"74; it secures and reinforces privileges and marginalization, leading to increasing oppression and discrimination.

Regardless of the category - grand, political or petty — corruption's adverse effects are most harmful on people that already have overlapping layers of disadvantage over them, and different examples can illustrate that. For instance, "a bribe demanded by a police officer may mean that a low-income family cannot afford school fees or even food to eat. Findings from Mexico show that the typical poor Mexican family can spend up to one-third of their income on bribes." ${ }^{75}$

Accordingly, UN Secretary-General Kofi Annan ${ }^{76}$ emphasized this reality in his speech on the adoption of the UNCAC by the General Assembly: "This evil

71 Human Rights Council, 10.

72 Barkhouse, Corruption, 6.

73 Transparency International, "Corruption by topic," n. p.

74 Alexander 2016, cited in Lewis, James. "Social Impacts of Corruption Upon Community Resilience and Poverty."Jàmbá Journal of Disaster Risk Studies 9, no. 1 (2017). doi:10.4102/jamba. v9i1.391. https://doi.org/10.4102/jamba.vgi1.391.7.

76 Annan, "UN Secretary-General Foreword to the United Nations Convention against Corruption (UNCAC)," n. p. 
phenomenon [corruption] is found in all countries big and small, rich and poor but it is in the developing world that its effects are most destructive. Corruption hurts the poor disproportionately by diverting funds intended for development, undermining a government's ability to provide basic services, feeding inequality and injustice, and discouraging foreign investment and aid. Corruption is a key element in economic under-performance, and a major obstacle to poverty alleviation and development."

In the same line, ESC-rights violations also affect the most vulnerable disproportionately, and the inequalities in accessing essential services needed for the enjoyment of those rights are alarming. Amnesty International ${ }^{77}$ explains that" $[\mathrm{t}]$ his is the result not only of a lack of resources but also of unwillingness, negligence, and discrimination by governments and others. Many groups are specifically targeted because of who they are; those on the margins of society are often overlooked altogether."

The full realization of economic, social, and cultural rights requires significant human, economic, technological, and other resources. Yet limited resources are not the principal cause of widespread violations of ESC-rights, and cannot be used as an excuse to deny specific individuals and groups these rights. "In many countries, ethnic minorities, Indigenous Peoples, women, members of the opposition or religious groups, people living with HIV/AIDS or disabilities and others risk deprivation as a result of discrimination, inequality, marginalization and injustice."78

States must protect people against risks and vulnerabilities in an equal and nondiscriminatory manner. Human rights obligations go beyond eliminating discrimination in law, policy, and practice, and require States to take special measures to protect the most vulnerable segments of society as a matter of priority, while taking measures to ensure universal protection progressively. ${ }^{79}$

Hence, considering that both corruption and ESC-rights violations affect marginalized people hardest, a human rights-based approach to corruption is fundamental in channeling anticorruption policies towards those who are most vulnerable and suffer the most destructive effects of corruption.

In this context, the analysis of Theme 3 emphasizes the socio-economic vulnerability of the victims in all the case studies, and once more the similarities between them serve as a springboard for theoretical reflections. In the first case, Lagos del Campo was not a powerful and wealthy businessman but an ordinary employee, and as such, his socioeconomic vulnerability put him in a position where he was in the most need for the protection of his ESC-rights. In the second case, the IACtHR explicitly recognized the layers of vulnerability and marginalization supported by Talía, resulting from her status as a female child living in poverty and with HIV.

Lastly, in the SERAP case, the vulnerability is intrinsic to the majority of children in Nigeria without access to primary education for obvious reasons - dueto their status

77 Amnesty International, "Human rights for human dignity," 13-14.

78 Amnesty International, 13-14.

79 General Assembly, "Report of the independent expert on the question of human rights and extreme poverty". 
as poor marginalized children, in a country marked by general inequality and prevalent poverty. Therefore, the case studies demonstrate the similarity of how the victims' vulnerability compounded the effects on ESC-rights caused by both corrupt and noncorrupt behaviors.

That being said, and taking into account that corruption is one modality of encroaching especially on ESC-rights, ${ }^{80}$ the combination of the findings within the previous themes with the analysis of Theme 3 brings to the conclusion that another value of a human rights-based approach to corruption is a more adequate response to the many facets of how corruption undermines ESC-rights of the most vulnerable disproportionately. It gives due attention to the critical vulnerability and subjective daily assaults on human dignity that accompany the overlapping deleterious impacts of corruption and inequality.

\section{Conclusion}

The evidence presented in this article has shown how corrupt behaviors undermine especially ESC-rights; and how a human rights-based approach to corruption is complementary to the traditional criminal law account, giving protagonism and agency to the victim, instead of focusing only on the perpetrator of the offense. Additionally, a people-centered approach to corruption addresses how it harms the most vulnerable disproportionally; and a human rights lens can help to understand the multifaceted reality of critical vulnerability and subjective daily assaults on human dignity that accompany the overlapping damages of corruption, oppression and inequality. " $[\mathrm{H}]$ uman rights, rights violations, and corruption should never be disconnected from the socioeconomic order and mainstream politics." 81

That being said, the conclusion is that, contrarily to the critique of "human rightism", the findings and socio-legal analysis indicate that there is no risk in overusing human rights language in the particular phenomena analyzed. Instead, there should be a shift towards using human rights language as a tool of legal empowerment, ultimately leading to social transformation. How could one argue an excessive "human rightism" when corruption undermines mostly the ECS-rights of marginalized people, who are also the main ones whose human rights are being violated regardless of any relationship to corrupt behaviors to begin with?

As already examined, criminal law language is not enough to address the complexities of corruption and its impacts on human rights, especially on the rights of the most vulnerable. "With regard to corruption, the purely criminal law approach has so far not worked all too well, and this suggests trying out complementary strategies." 82

\footnotetext{
8o Peters, Humanisation.

81 Morten Koch Andersen, "Why Corruption Matters in Human Rights."Journal of Human Rights

Practice 10, no. 1 (2018): 182. doi:10.1093/jhuman/huyoo4. https://doi.org/10.1093/jhuman/ huyoo4.

82 Peters, Corruption, 1286.
} 
Therefore, human rights language can, more than be only complementary, be also empowering.

In this sense, people whose ESC-rights are affected are mainly the ones who need them most, since, as already discussed, corruption affects the poor and marginalized disproportionally. Therefore, the rationality of applying a human rights-based approach to corruption as a tool of legal empowerment is that this institution aims to strengthen the disadvantaged through the use of law,,$^{83}$ and in this case, the law in question is precisely international human rights law.

Consequently, this conclusion provokes the follow-up question: How can a human rights-based approach to corruption empower those most affected by it?

The social accountability dimension of legal empowerment is the aspect of this institution that appropriately answers this question. "The social accountability dimension of Legal empowerment illuminates the links between legal empowerment and social accountability - that is, the ability of society and its citizens to hold governments accountable for service delivery and other functions." ${ }^{84}$ Therefore, it enables to hold governments accountable not only for corruption itself, but for its combination of overlapping harmful consequences that a human rights-based approach to corruption can bring to light.

In this regard, Professor Peters adds that: "[ $\mathrm{t}]$ he classical argument [supporting a human rights-based approach to corruption] is 'empowerment.' The human rights approach can highlight the rights of persons affected by corruption, such as the rights to safe drinking water and free primary education, and show these persons how, for instance, the misappropriation of public funds in those areas interferes with their enjoyment of the goods to which they are entitled. In that way, affected persons would be empowered to denounce corruption to which they otherwise would be helplessly exposed." 85

The argument of the risk of "human rightism" could only make sense in an idealistic world where anti-corruption law, human rights law, and even the rule of law, ultimately, are as effective in practice as they are meant to be in the letter of the law. However, the main problem with this interpretation is the same "old problem" very well known by human rights lawyers, practitioners, and activists: there is a significant difference between the letter of human rights law (and also anti-corruption law, in this case), and the actual implementation and effectiveness of these laws. The socalled implementation gap of international human rights law cannot be disregarded, especially when combined with overlapping harms caused by corruption and inequality. This study argues that a human rights-based approach to corruption is one possible strategy to just begin to remedy that.

\footnotetext{
83 Golub, Empowerment, 5

84 Golub, Empowerment 3.

85 Peters, Corruption, 1276.
} 
As Professor Peters ${ }^{86}$ wisely emphasizes: "In acknowledgment of the dangers of exaggerated rightism, I insist on the added value of a focus on rights in combating corruption. This also means to refute the current overblown critique of rights. As long as that critique does not present any meaningful alternative to (human) rights as instruments of social struggle and as vehicles of emancipation it amounts to no more than a 'debilitating quietism"' 87 . "[W]hile many of the critiques of human rights raise important concerns, they fail to meaningfully address the central question of the relationship between human rights and social struggles." 88

"What Patricia Williams wrote 20 years ago for people of color in the United States remains true for large populations worldwide: "Rights" feels so new in the mouths of most black people. It is still so deliciously empowering to say.' ${ }^{89}$ Rights transform victims into citizens. Moreover, these citizens are needed to build states and global governance institutions that work." 90

Therefore, considering the political and socio-economic reality of the phenomena here studied; using the case data and the findings of the directed content analysis as a springboard to apply the adopted theories and concepts, this section concludes that there are interconnected and mutually reinforcing socio-legal values in applying a human rights lens to combating corruption. The values are: (i) it is an improvement towards the justiciability of ESC-rights; (ii) it is a change of paradigm from an insufficient criminal approach to a focus on social harm; and (iii) it is a more satisfactory approach to the overlapping harmful effects of corruption and inequality.

\section{Bibliography}

American Convention on Human Rights. (Pact of San Jose Costa Rica). Organization of American States. November 22, 1969. https://www.oas.org/dil/access_to_ information_American_Convention_on_Human_Rights.pdf.

Amnesty International. "Human Rights for Human Dignity: A Primer on Economic, Social and Cultural Rights." Updated 2014. Accessed March 8, 2019. https://www. amnesty.org/download/Documents/80oo/pol340012014en.pdf.

Andersen, Morten Koch. "Why Corruption Matters in Human Rights."Journal of Human Rights Practice 10, no. 1 (2018): 179-9o. doi:10.1093/jhuman/huyoo4. https://doi. org/10.1093/jhuman/huyoo4.

Annan, Kofi. "UN Secretary-General Foreword to the United Nations Convention Against Corruption (UNCAC)." United Nations, 2003.

86 Peters, Corruption, 1276.

87 Peters, Corruption, 4.

88 Paul O'Connell, "On the Human Rights Question," Human Rights Quarterly 40, no. 4 (2018): 962-63. doi:10.1353/hrq.2018.0051. https://doi.org/10.1353/hrq.2018.0051.

89 Williams 1987, cited in Peters, Humanisation, 4.

90 Peters, Humanisation, 4. 
Banik, Dan. "Legal Empowerment as a Conceptual and Operational Tool in Poverty Eradication." Hague Journal on the Rule of Law 1, no. o1 (2009): 117-31. doi:10.1017/S 1876404509001171. https://doi.org/10.1017/S1876404509001171.

Barkhouse, Angela, Hugo Hoyland, and Marc Limon. "Corruption: A Human Rights Impact Assessment." Updated 2018. Accessed January 20, 2019. https://www. universal-rights.org/urg-policy-reports/corruption-human-rights-impactassessment/.

Bryman, Alan. Social Research Methods. Fifth edition. Oxford: Oxford University Press, 2016.

Chynoweth, Paul. "Legal Research." InAdvanced Research Methods in the Built Environment. Edited by Andrew Knight and Leslie Ruddock. Chichester, West Sussex, United Kingdom, Ames, Iowa: Wiley, 2008.

Feenan, Dermot. "Exploring the 'Socio' of Socio-Legal Studies.” InExploring the 'Socio'of Socio-Legal Studies. Vol. 38. Edited by Dermot Feenan, 3-19. Palgrave Macmillan Socio-Legal Studies. London: Macmillan Education UK; Imprint; Palgrave, 2013.

General Assembly. "Report of the Independent Expert on the Question of Human Rights and Extreme Poverty: A/65/259." United Nations, 2010. https://documentsdds-ny.un.org/doc/UNDOC/GEN/N1o/478/79/PDF/N1047879.pdf?OpenElement.

Golub, Stephen. "What Is Legal Empowerment? An Introduction." Updated 2010. Accessed February 2, 2019. https://www.files.ethz.ch/isn/13810o/Golub_ Introduction.pdf.

Gonzales Lluy Y Otros V. Ecuador. Inter-American Court of Human Rights, September 1, 2015. Accessed March 28, 2019. http://www.corteidh.or.cr/docs/casos/articulos/ seriec_298_esp.pdf.

Hensgen, Leonie. "Corruption and Human Rights_-Making the Connection at the United Nations." Max Planck Yearbook of United Nations Law Online 17, no. 1 (2013): 197-219. Accessed May 9, 2018. doi:10.1163/18757413-90oooo85. http://booksandjournals. brillonline.com.ezproxy.ub.gu.se/content/journals/10.1163/18757413-90000085.

Hsieh, Hsiu-Fang, and Sarah E. Shannon. "Three Approaches to Qualitative Content Analysis."Qualitative health research 15, no. 9 (2005): 1277-88. doi:10.1177/1049732305276687. https://doi.org/10.1177\%2F1049732305276687.

Human Rights Council. "Final Report of the Human Rights Council Advisory Committee on the Issue of the Negative Impact of Corruption on the Enjoyment of Human Rights: A/HRC/28/73." United Nations, 2015. https://www.ohchr.org/en/hrbodies/ hrc/regularsessions/session28/pages/listreports.aspx.

Lagos Del Campo V. Peru. Inter-American Court of Human Rights, August 31, 2017. http://www.corteidh.or.cr/docs/casos/articulos/seriec_34O_esp.pdf.

Lewis, James. "Social Impacts of Corruption Upon Community Resilience and Poverty."Jàmbá Journal of Disaster Risk Studies 9, no. 1 (2017). doi:10.4102/jamba. vgi1.391. https://doi.org/10.4102/jamba.vgi1.391.

Mumuni, Adetokunbo. "Legal Remedies for Grand Corruption: Litigating Corruption in International Human Rights Tribunals: SERAP Before the ECOWAS Court." 
Updated 2016. Accessed March 3, 2019. https://www.opensocietyfoundations.org/ publications/legal-remedies-grand-corruption.

O'Connell, Paul. “On the Human Rights Question."Human Rights Quarterly 40, no. 4 (2018): 962-88. doi:10.1353/hrq.2018.0051. https://doi.org/10.1353/hrq.2018.o051.

Pellet, Alain. "Human Rightism" and International Law." The Italian Yearbook of International Law Online 10, no. 1 (2000): 3-16. doi:10.1163/22116130oXooo13. https://doi.org/10.1163/22116130oXooo13.

Peters, Anne. "Corruption as a Violation of International Human Rights."European Journal of International Law 29, no. 4 (2018): 1251-87. doi:10.1093/ejil/chyo7o. https://doi.org/10.1093/ejil/chyo7o.

Peters, Anne. "The Risk and Opportunity of the Humanisation of International AntiCorruption Law: A Rejoinder to Kevin E. Davis and Franco Peirone." InEJIL: Talk! The Blog of the European Journal of International Law., 2019. Accessed March 26, 2019. https://www.ejiltalk.org/the-risk-and-opportunity-of-the-humanisationof-international-anti-corruption-law-a-rejoinder-to-kevin-e-davis-and-francopeirone/\#more-16904.

Raoul Wallenberg Institute. "Anti-Corruption and Human Rights: How to Become Mutually Reinforcing." Updated 2018. Accessed May 24, 2018. http://rwi.lu.se/ publications/anti-corruption-human-rights-become-mutually-reinforcing/.

Raoul Wallenberg Institute. “The Nexus Between Anti-Corruption and Human Rights.” Updated 2018. Accessed February 11, 2019. https://rwi.lu.se/publications/nexusanti-corruption-human-rights/.

Rose, Cecily. "The Limitations of a Human Rights Approach to Corruption."International and Comparative Law Quarterly 65, no. 2 (2016): 405-438. Accessed February 11, 2019. doi:10.1017/S oo20589316oooo38. https://doi.org/10.1017/Soo20589316oooo38.

The Registered Trustees of the Socio-Economic Rights and Accountability Project (SERAP) V. The Federal Republic of Nigeria and Universal Basic Education Commission. Community Court of Justice of the Economic Community of West African States, November 30, 2010. https:/ihrda.uwazi.io/en/document/ qrb6wqua4frswtjqwichxgvi?page=1.

The Secretariat of the Inter-American Court of Human Rights. "Non Official Brief: I/A Court H. R., Case of Gonzales Lluy Et Al. V. Ecuador. Preliminary Objections, Merits, Reparations and Costs. Judgment of September 1, 2015. Series C No. 298." Accessed 5/23/2019. http://www.corteidh.or.cr/cf/Jurisprudencia2/overview. cfm?doc=1576\&lang=en.

The Special Rapporteurship on Economic, Social, Cultural and Environmental Rights of the Inter-American Commission on Human Rights. "The Special Rapporteurship on Economic, Social, Cultural and Environmental Rights Welcomes the Historic Decision of the Inter-American Court of Human Rights on Justiciability in Matters of ESCER: No. D 181/17." News release. 2017. Accessed March 26, 2019. http://www. oas.org/en/iachr/media_center/PReleases/2017/181.asp. 
Legal Values of a Human Rights-Based Approach to Corruption

Transparency International. "Corruption by Topic: Poverty and Development." Accessed March 27, 2019. https://www.transparency.org/topic/detail/poverty_ and_development.

United Nations Convention Against Corruption. UNCAC. UN General Assembly. October 31, 2003. https://www.unodc.org/unodc/en/corruption/tools_and_publications/ UN-convention-against-corruption.html.

Wheeler, Sally, and P. A. Thomas. "Socio-Legal Studies." InLaw $(S)$ Futures. Edited by D. Hayton, 267-79. Hart Publishing, 2000.

\section{(2)}

Bruna de Castro e Silva holds a JD from the University of Sao Paulo, is an M. A. candidate in Human Rights Policy and Practice, at the University of Gothenburg, and a Lawyer. Expertise, interests and research subjects include, but are not limited to, human rights, anti-corruption, good governance, and development. She has interned at The Program on Governance and Local Development, Political Sciences Department, at the University of Gothenburg; and at the Organization of American States (OAS), Washington, D. C., US. At the OAS, she worked for the Mechanism for the Follow-Up on the Implementation of the Inter-American Convention against Corruption (MESICIC), assisting member countries in the drafting of policy reforms related to anti-corruption and transparency. 